Images in...

\title{
Colossal hydronephrosis caused by pelvi-ureteric junction obstruction
}

Hosam El-Din Matar, Seneviratne Lasantha, Mahmoud Al-Akraa

Department of Urology, Royal Free Hospital, London, UK

Correspondence to Dr Hosam El-Din Matar, hematar@doctors.org.uk

\section{DESCRIPTION}

A 36-year-old man presented with increasingly colicky left abdominal pain radiating to left loin with normal haematological and biochemical investigations. His ultrasound showed gross left hydronephrosis which was followed by CT with standard urogram protocol, CT images are presented here (figure 1). There is gross severe hydronephrosis of the left kidney with a significantly enlarged renal pelvis; the transition point noted at the pelvi-ureteric junction (PUJ) consistent with a PUJ obstruction. There is enhancement of the residual atrophic renal cortex which is extremely thin and almost absent in areas. There was also significantly delayed excretion of the left kidney with a crescent of contrast excretion noted in the
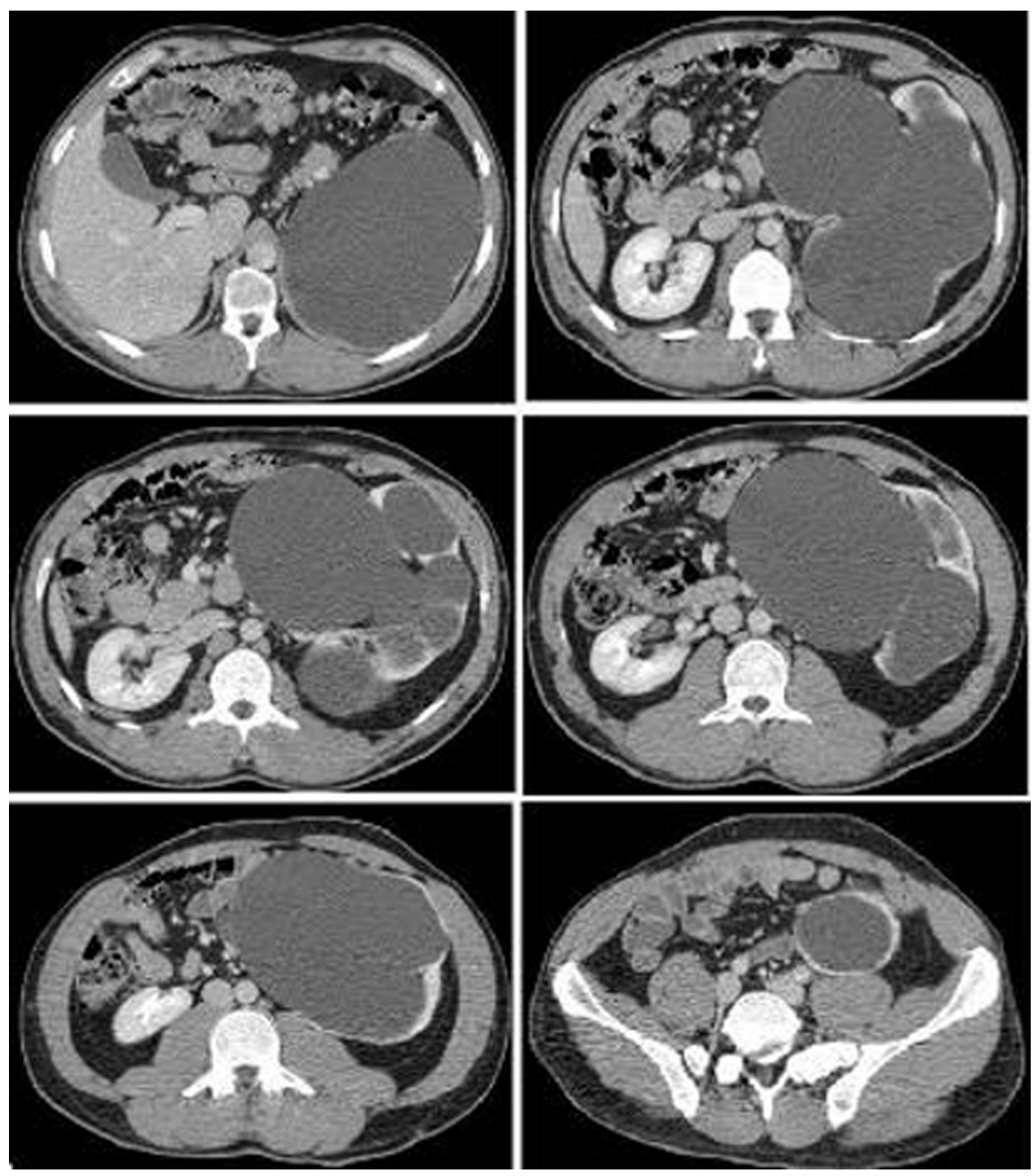

Figure 1 CT urogram: colossal left hydronephrosis. 


\section{BMJ Case Reports}

dependent portion of the inferior calyces and pelvis. The right kidney has normal appearance with delayed scan (at $25 \mathrm{~min}$ ) demonstrating normal opacification of the pelvicaliceal system and ureter on the right. Tc-99m-labeled mercaptoacetyltriglycine (Tc-99m MAG3) renogram confirmed obstructed non-functioning left kidney and a normally functioning right kidney. Patient underwent a left nephroureterectomy with no malignancy found. He had uneventful recovery. No cause of the obstruction is identified in this patient but it is likely to be congenital or childhood related pathology.

Competing interests None.

Patient consent Obtained.

This pdf has been created automatically from the final edited text and images.

Copyright 2011 BMJ Publishing Group. All rights reserved. For permission to reuse any of this content visit http://group.bmj.com/group/rights-licensing/permissions.

BMJ Case Report Fellows may re-use this article for personal use and teaching without any further permission.

Please cite this article as follows (you will need to access the article online to obtain the date of publication).

Matar HE, Lasantha S, Al-Akraa M. Colossal hydronephrosis caused by pelvi-ureteric junction obstruction. BMJ Case Reports 2011;10.1136/bcr.10.2011.4913, Published XXX

Become a Fellow of BMJ Case Reports today and you can:

- Submit as many cases as you like

- Enjoy fast sympathetic peer review and rapid publication of accepted articles

- Access all the published articles

- Re-use any of the published material for personal use and teaching without further permission

For information on Institutional Fellowships contact consortiasales@bmjgroup.com

Visit casereports.bmj.com for more articles like this and to become a Fellow 